ISSN 1991-8631

\title{
Late season sugarcane performance as affected by soil water deficit at the yield formation stage in commercial farms of northern Ivory Coast
}

\author{
Crépin B. PÉNÉ *, Marco H. OUATTARA and Sylvain G. KOULIBALY \\ SUCAF CI/Ferké Sugar mills, 01 P.O. Box 1967 Abidjan, Ivory Coast. \\ *Corresponding author; E-mail: cbpene@yahoo.fr, bpene@sucafci.somdiaa.com
}

\begin{abstract}
A field trial was carried out in Ferké 2 Sugar mill located in northern Ivory Coast, in order to study sugarcane growth and yield response to deficit irrigation imposed over the yield formation stage. The crop used was a first ratoon Co 957, a non flowering late season sugarcane variety. The experiment was completely randomized following a one-factor design with 4 water deficit treatments in 3 replicates. It came out that the optimum water deficit treatment reached $20 \%$, i.e., $80 \%$ of crop water requirements were satisfied through irrigation. That treatment gave an irrigation water use efficiency of $7.9 \mathrm{~kg}$ cane $/ \mathrm{m}^{3}$ or $0.98 \mathrm{~kg} \mathrm{sugar} / \mathrm{m}^{3}$. Relatively low crop growth rates $(0.2-0.4 \mathrm{~cm} /$ day $)$ as well as low cane yields $(24.5-78.4 \mathrm{t} / \mathrm{ha})$ were obtained as a result of an intensive and persistent dry season occurred over the yield formation stage. In line with prevailing climatic conditions, cane juice quality measured was particularly high (15.7 - 16.7 pol\%) on Co 957 which used to be a moderately performing variety in Ferké 2 sugar mill.
\end{abstract}

(C) 2012 International Formulae Group. All rights reserved.

Keywords: Water deficit, yield formation, growth rate, cane yield, water use efficiency, Ivory Coast.

\section{INTRODUCTION}

Previous studies carried out in commercial sugarcane plantations of Ferké 1 as well as Ferké 2 mills in northern Ivory Coast showed that water was the main yield limiting factor (Péné and Koulibaly, 2011). Water is seen as a complex factor as its availability is climate and soil texture dependent. To mitigate rainfall hazards and better meet sugarcane crop water requirements, sound irrigation investments are being made every year by the SUCAF-CI company. Nevertheless, sugar produced by the company through both mills at yearly basis is still strongly dependent on rainfall patterns. That's why water management efforts for a better impact of irrigation on cane yields are a major concern. More over, it was shown that late season sugarcane stalk growth and yield response to irrigation on Ivorian sugar mills was quite low for most varieties under 
cultivation at that period like Co 957, FR 8069, R 570 (Péné and Kéhé, 2005).

Improving crop yields in order to achieve the competitiveness of sugarcane industry is an important issue in the Ivory Coast. To do so, a lot of emphasis is being put on growing high yielding cane varieties as well as adopting improved and cost-effective cropping practices such as irrigation deficit, minimum soil tillage, green cane harvesting, double row planting for better yields and weed control, legume-break sugarcane farming to enhance soil health, soil organic matter content and reduce $\mathrm{N}$-fertilizer cost, as well as precision-fertilization over cane rows (Péné and Assa, 2005).

The practice of irrigation deficit over less sensitive cane growth stages to water stress for increasing the irrigation productivity in terms of $\mathrm{kg}$ of cane $/ \mathrm{m}^{3}$ of water is a key recommendation, irrigation being the most costly sugarcane production factor in Ivory Coast and number of west African countries (Péné et al., 2001; Péné et Édy, 1999).

Water was shown as the first yield limiting factor of sugarcane in Ivory Coast due to unreliable rainfall as well as irrigation constraints of sugarcane plantations, in terms of surface water resources and electricity power generation for water pumping or irrigation equipment (Péné et Assa, 2003). However, cane yields obtained in commercial plantations could not be always clearly explained by irrigation water applied, although the other key production factors were kept at their optimum levels. That's why cane yield estimates made on yearly basis are rather subjective and therefore unreliable.

The impact of irrigation deficit as a strategy to increase crop water use efficiency and therefore enhance sustainable water savings was reported on sugarcane as well as number of legume, cereal or tree crops by several authors (Garcia-Tejero et al., 2010; Kirda, 2010; Kirda et al, 2005).
The study objective was to impose irrigation deficit over the yield formation stage of late season sugarcane in order to increase crop water use efficiency.

\section{MATERIALS AND METHODS}

\section{Site characteristics}

The study was carried out in a commercial field of Ferké 2 sugar mill in northern Ivory Coast which is located $40 \mathrm{~km}$ away from the city of Ferkessédougou $\left(09^{\circ} 35^{\prime} \mathrm{N}, \quad 05^{\circ} 12 \mathrm{~W}, \quad 330 \mathrm{~m}\right.$ ASL). The prevailing climate is tropical dry with a unimodal rainfall pattern averaging 1200 $\mathrm{mm} /$ year. The 7 month rainy season takes place from April to October, August and September being highly wetted with a total rainfall of 500-600 $\mathrm{mm}$. The 5-month dry season starting from November to March, is marked by a hot as well as dry wind originated from Sahara, namely the harmattan (or northern trade wind) which prevails from November to January with the highest magnitude of daily temperatures $\left(+10-20{ }^{\circ} \mathrm{C}\right)$. The vegetation is Guinea savannah with some thin rain forests along waterways. Soils are mainly feral soils and occasionally alluvial soils or hydromorphic soils in valley bottoms as well as in uplands where water infiltration is limited by impermeable layers.

The Ferké 2 sugar mill covers a total cultivated land surface of 8000 ha which are mainly under sprinkler as well as drip irrigation (Figure 1).

\section{Sugarcane crop}

The cane variety investigated (Co 957) is widely grown in Ferké 2 sugar mill as a late season crop over about $40 \%$ of total cultivated land (2300 ha). Only the first ratoon cane, harvested on March 20, 2007, was investigated. The plant crop was harvested on March 17, 2006. Over a late season cane crop, the irrigation management involves 2 watering campaigns. The first one started at early 


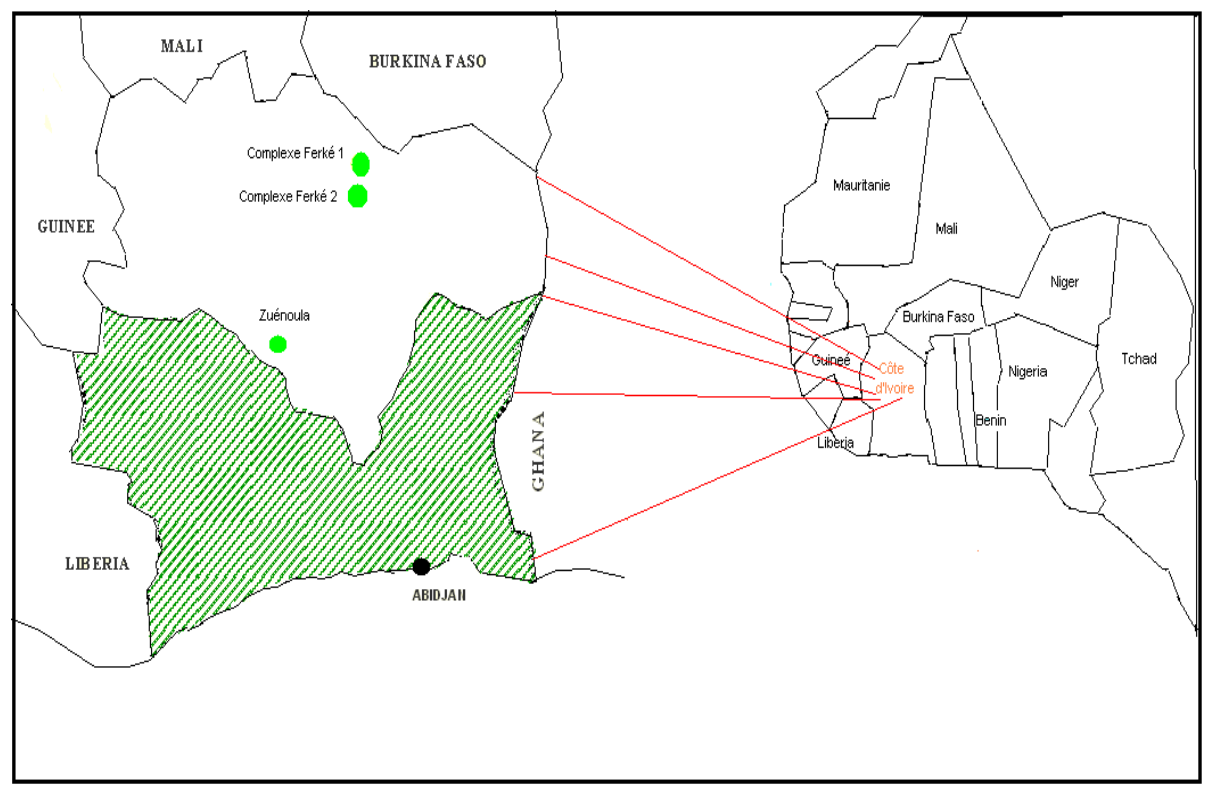

Figure 1: Ferké 1 \& 2 sugar mills located in northern Ivory Coast, West Africa.

growth stage and ended at the stem elongation stage in mid July. The second one took place at the yield formation stage which started from early November 2006 to late February 2007, i.e., approximately three weeks prior to harvest.

\section{Experimental design}

The study was laid out on the 104 numbered commercial fields of 22 ha. Apart from the yield formation stage, irrigation water was applied uniformly in the field following routine management practices. Four watering regimes were imposed over the yield formation stage as follows:

T0: zero water deficit at yield formation (control);

T20: $20 \%$ water deficit at yield formation;

T80: $80 \%$ water deficit at yield formation;

T100: 100\% water deficit at yield formation (control).

The experiment was laid out following a RCB with 4 irrigation treatments in 3 replicates. Every plot was 1 ha wide, i.e., 16 cane rows of $432 \mathrm{~m}$ in length with $1.5 \mathrm{~m}$ row spacing. Stalk elongation measurements were made twice a month (every two weeks) over a sample of 10 canes randomly chosen within all individual plots. All key agronomic factors, namely fertilization, weeding and soil tillage, were kept constant except for soil water regimes at the yield formation stage. Fertiliser rates applied in the field at early crop growth stage were $300 \mathrm{~kg} / \mathrm{ha}$ of urea $(46 \% \mathrm{~N}), 100 \mathrm{~kg} / \mathrm{ha}$ of super phosphate $(45 \%$ $\left.\mathrm{P}_{2} \mathrm{O}_{5}\right)$ and $350 \mathrm{~kg} / \mathrm{ha}$ of potassium chloride $\left(60 \% \mathrm{~K}_{2} \mathrm{O}\right)$.

\section{Irrigation system}

Watering was done following a full covering sprinkler irrigation system with $18 \mathrm{~m}$ x $24 \mathrm{~m}$ grid where PVC laterals as well as sprinklers were permanently installed over the crop cycle. Irrigation water was applied weekly following a climate-based water balance equation regarding the normal watering regime, i.e. zero water deficits, as indicated below:

$\mathrm{I}=\mathrm{K}_{\mathrm{c}} \times \operatorname{Pan}_{\text {Evap }}-\mathrm{P}$

Where: $K_{c}, P_{\text {Evap }}$ and $P$ stand for crop coefficient, class A pan evaporation and precipitation, respectively. 


\section{Sol water balance}

Crop water uptake was assessed using a soil water balance model which is driven by the following simplified equation:

$\mathrm{P}+\mathrm{I}-(\mathrm{ETa}+\mathrm{D}+\mathrm{R})=\Delta \mathrm{S}$ over a given period

Where: P (precipitation, measured), I (irrigation depth applied, as previously calculated), ETa (actual evapotranspiration, calculated), D (deep percolation, calculated by difference, the soil available moisture being determined), $\mathrm{R}$ (runoff which is neglected).

The soil in the experimental site was sampled over $30 \mathrm{~cm}$ depth at five different locations randomly chosen before setting up the trial in order to determine soil physical and chemical properties.

\section{Field irrigation efficiency}

The field irrigation efficiency, expressed in $\mathrm{kg}$ of cane or recoverable sucrose per cubic meter of water, is defined as the ratio of yield increase resulting from watering with respect to the rainfed treatment over the irrigation depth required. Therefore, the irrigation water use efficiency (IWUE) was assumed to be higher or at least equal to the irrigation water application efficiency (IWAE). Under good irrigation management practices, both irrigation efficiency data are supposed to be close for a given treatment:

IWAE $=\left(\mathrm{Y}_{\mathrm{i}}-\mathrm{Y}_{\mathrm{r}}\right) /\left(\mathrm{I}_{\mathrm{i}}-\mathrm{T}_{\mathrm{r}}\right)$ and IWUE = $\left(\mathrm{Y}_{\mathrm{i}}-\mathrm{Y}_{\mathrm{r}}\right) /\left(\mathrm{ETa}_{\mathrm{i}}-\mathrm{ETa}_{\mathrm{r}}\right)$

Water use efficiency (WUE) is defined as the ratio of cane stalk or recoverable sucrose yield over water uptaken by the crop (ETa):

$\mathrm{WUE}=\mathrm{Y}_{\mathrm{i}} / \mathrm{ETa}_{\mathrm{i}}$

Where:

$\mathrm{Y}_{\mathrm{i}}$ : yield of any irrigation treatment $\mathrm{I}_{\mathrm{i}}$, the semi-rainfed $\mathrm{I}_{\mathrm{r}}$ included; included.

Eta $_{\mathrm{i}}$ : Eta of any $\mathrm{I}_{\mathrm{i}}$, the semi-rainfed $\mathrm{I}_{\mathrm{r}}$

\section{Statistical analysis}

Cane and sugar yields as well as juice quality parameters regarding all experimental plots were separately analysed using the variance linear model corresponding to the randomised complete block design in the Statistica software package (vers. 6.0 for Windows XP). Responses to each water deficit treatment were examined by its comparison with the control treatment fully irrigated (T0).

\section{RESULTS AND DISCUSSION \\ Cane and sugar yields}

Highly significant differences in cane as well as sugar yields were observed within irrigation treatments. Cane yields were affected by as much as $0,-18$ and $-69 \%$ due to soil water deficit involving T20, T80 and T100 irrigation treatments respectively. Recoverable sugar yields were also affected by as much as $-17.5,-21$ and $-69 \%$ regarding T20, T80 and T100 irrigation treatments respectively. In contrast, all juice quality parameters were not significantly affected.

\section{Cane yield response to soil water deficit}

Cane yield response to irrigation deficit as well as ETa deficit has a decreasing parabolic shape, which suggests the moderately stressed $\mathrm{T} 20 \%$ as the optimum level (Figures 2 and 3).

\section{Crop growth response}

Except for the non-irrigated treatment, water deficit at the yield formation stage did not significantly affect cane stalk growth (Figure 4).

A lower stalk growth response to irrigation was observed over the yield formation stage with an elongation rate of 0.2 - $0.4 \mathrm{~cm} /$ day from December 2006 to march 2007, as opposed to $0.6 \mathrm{~cm} /$ day recorded in mid-November 2006 (Figure 5). A much lower stalk elongation rate was observed on the non-irrigated treatment $\mathrm{T} 100$ with 0.1 cm/day from December 2006 to March 2007, as opposed to $0.4 \mathrm{~cm} / \mathrm{d}$ measured in November 2006.

\section{Prevailing climatic conditions}

Climatic conditions over the dry season in 2006/2007 cropping season were quite favourable for cane ripening as compared to 
that of 2005/06. Air moisture content and average temperature magnitudes were kept respectively lower $(44 \%)$ and higher $\left(14.9^{\circ} \mathrm{C}\right)$ in $2006 / 07$ as compared to $2005 / 6$ with $50 \%$ and $13.9{ }^{\circ} \mathrm{C}$ (Figures 6a and 6b). That might have affected cane growth response to irrigation water at the yield formation stage under investigation.

\section{Soil physical and chemical properties}

Soil in the experimental field is moderately acid $(\mathrm{pH}=6.5)$ and therefore optimum for sugarcane cultivation. It is also coarse textured, with total available moisture (TAM) of $70 \mathrm{~mm}$ over $60 \mathrm{~cm}$ depth. The chemical status before setting up the trial was marked by a lower base saturation ratio $(24 \%)$ and a $\mathrm{C} / \mathrm{N}$ ratio too high (15) which suggest a weathered soil with a slow organic matter mineralization process (Table 2). Soil nitrogen and potassium contents were quite low with $0.04 \%$ and $0.13 \mathrm{meq} / 100 \mathrm{~g}$ respectively, resulting from crop uptake but also from leaching and volatilization processes as far as nitrogen was concerned. In contrast, available phosphorous content was high (24 ppm) despite crop uptake, that element being much stable in the soil profile than nitrogen and potassium.

\section{Field irrigation efficiency}

Irrigation water use efficiency resulting from the non-stressed or fully irrigated treatment T0 $\left(8.2 \mathrm{~kg} \quad \mathrm{cane} / \mathrm{m}^{3}\right)$ was not significantly different from that of T20 irrigation treatment $\left(7.9 \mathrm{~kg}\right.$ canne $\left./ \mathrm{m}^{3}\right)$. Therefore, additional irrigation water applied on T0 with respect to T20 in order to meet crop water requirements was not profitable (Figure 7).

\section{Climatic conditions and cane stalk elongation \\ Very low elongation rates observed over the yield formation stage, despite watering of some treatments and Co 957 being a non-flowering variety, could be explained by an intensive drought enhanced by a much lasting fresh weather (harmattan) which took}

place over 3.5 - 4 months instead of $1.5-2$ as usual. As a result, a moderately performing variety like Co 957 gave high sucrose content in Ferké 2. On that location, the harmattan period used to be shorter (December-january) so that Co 957 could maintain a better growth rate at the yield formation stage and compensate its moderate sucrose content by higher cane yields.

\section{Soil fertility and sugarcane yields}

Lower cane yields obtained in the experiment regarding the fully irrigated treatment (78 t/ha) as well as several plantations in Ferké 2 (75 t/ha on average) might be explained partly by poor performance of old varieties like Co 957, NCo 376, M 3145 and $Q 75$ still under cultivation over about $60 \%$ of total area, but also by soil fertility decline. That decline might have resulted from poor agricultural practices like cane burning at harvest and conventional soil tillage still in use since early 1970. To mitigate that trend, mechanized green cane harvesting, cane trash blanketing, minimum soil tillage as well as sugarcane-based legume crop rotation system are being promoted in Ferké 2 plantations since 2006. Such a new farming system in sugarcane is of concern in most large sugarcane-producing countries (Robertson and Thorburn, 2007a; Pankhurst et al., 2003; Doerr and Cerda, 2005).

\section{Cane yields and quality in commercial fields \\ Cane yield reduction with respect to} yield predictions on late season varieties was high $(10-20 \%)$ due to exceptional climatic conditions over the yield formation stage in Ferké 2. In contrast, cane juice quality was quite high with $16-17 \%$ of sucrose content and $95-96 \%$ of purity obtained in the field. This has mitigated sugar production loss as compared to initial estimates. Some additional sugar production (10-15\%) was obtained compared to estimates, as better cane yields and quality were achieved. Eventually, initial production estimates were met by $99 \%$ in 
commercial plantations and by $112 \%$ in village plantations.

\section{Soil water deficit at yield formation of late season cane varieties}

The study showed the relevance of $20 \%$ water deficit imposed at the yield formation stage of Co 957, as a non-flowering lateseason cane variety, in order to increase the field irrigation efficiency. This finding was not in line with results from a similar study carried out on a neighbouring experimental station (Péné et al., 1997) which suggested a normal watering regime at yield formation on the same variety because of its growth potential at that growth stage. This suggests the yield response of that variety to water deficit is dependent on the intensity as well as the duration of the harmattan period prevailing over the yield formation stage under late irrigation season. As far as some late cane varieties prone to flowering like $M$ 3145 and $R 570$ were concerned, previous studies reported a limited yield response to irrigation at that growth stage and the profitability of managing a moderate water deficit by 20 to $30 \%$, in order to increase field irrigation efficiency and achieve some substantial water savings (Péné et al., 2001). In general, the study shows that cane yield response to water deficit is dependent on variety, crop growth stage, pedo-climatic conditions as well as the watering strategy adopted in line with some investigations undertaken elsewhere (Gaudin et al., 1999; Martiné, 1999).

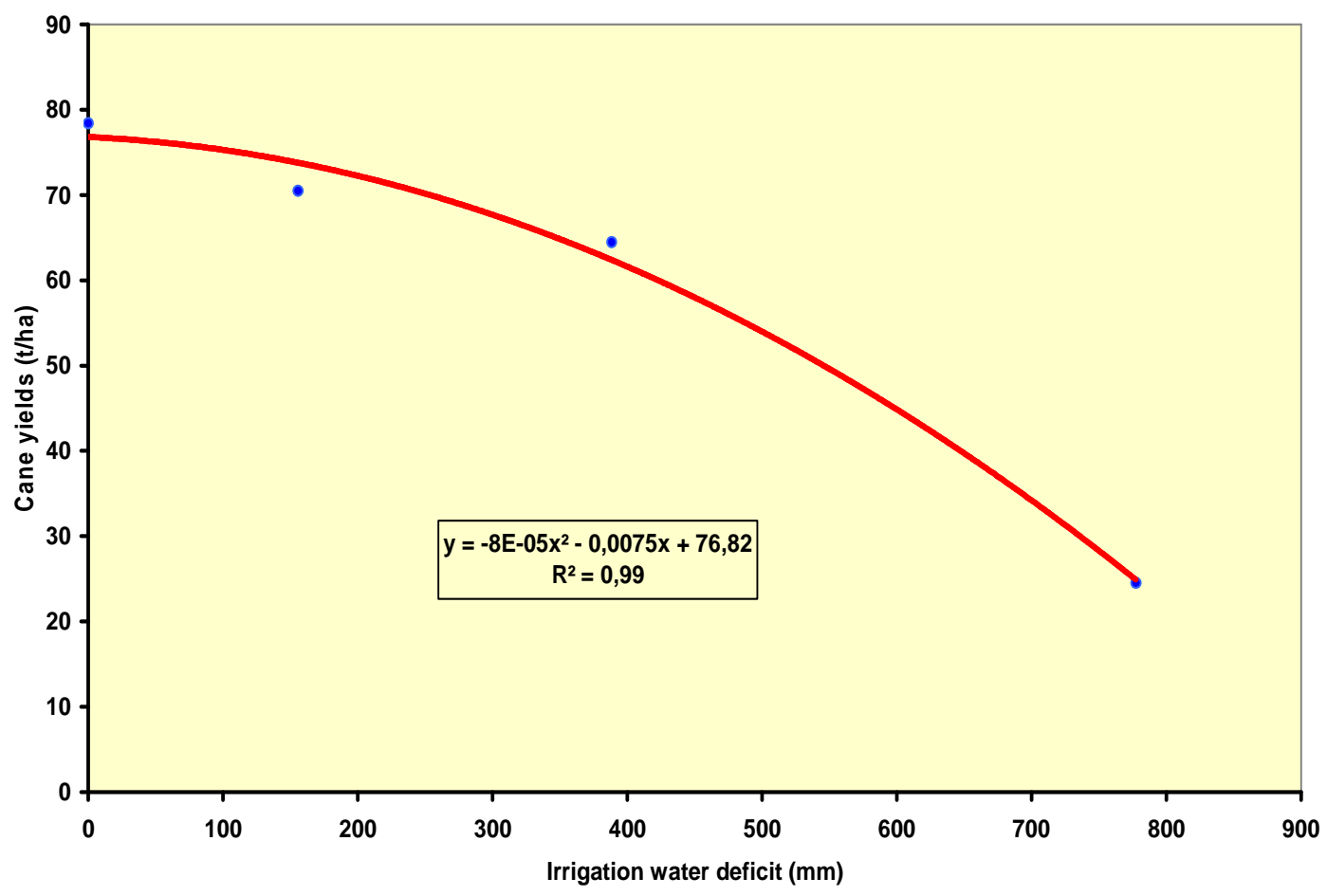

Figure 2: Cane yield response to irrigation water deficit imposed over the yield formation stage in Ferké 2 sugar mill (northern Ivory Coast). 


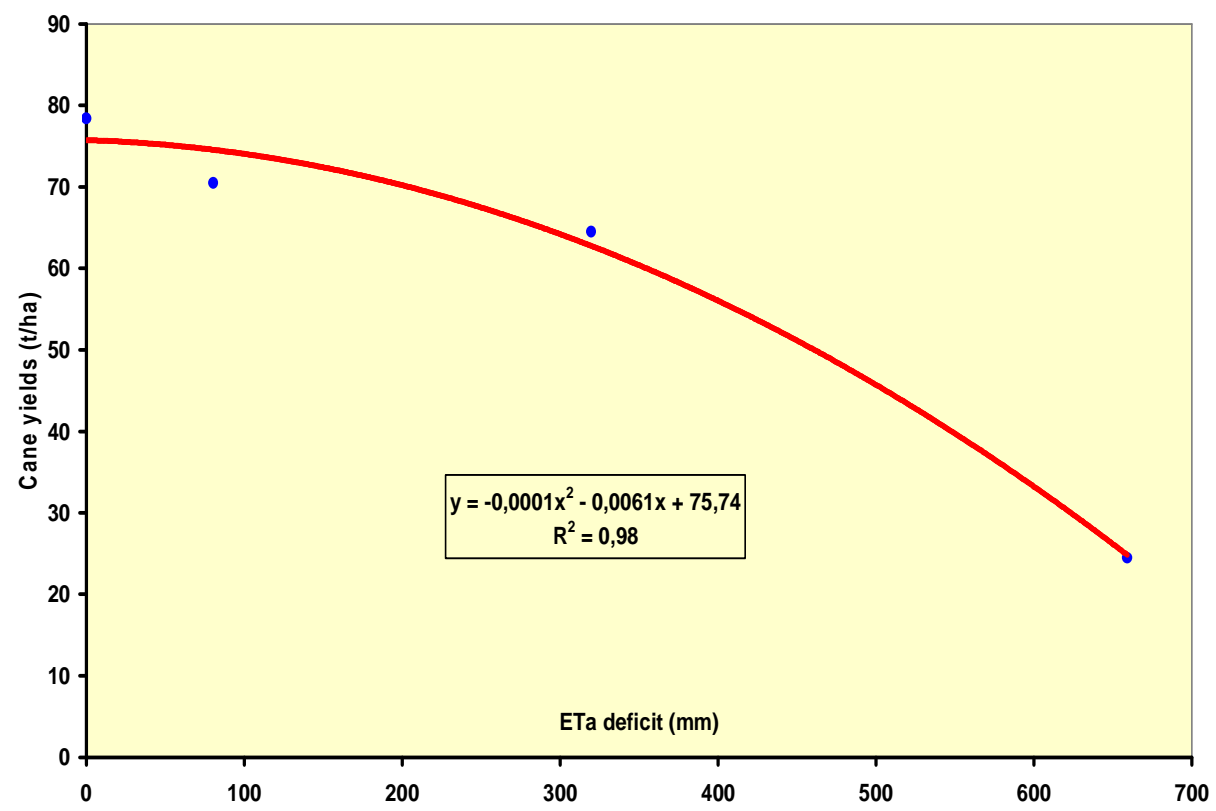

Figure 3: Cane yield response to actual evapotranspiration deficit imposed over the yield formation stage of a late season variety in Ferké 2 sugar mill (northern Ivory Coast).

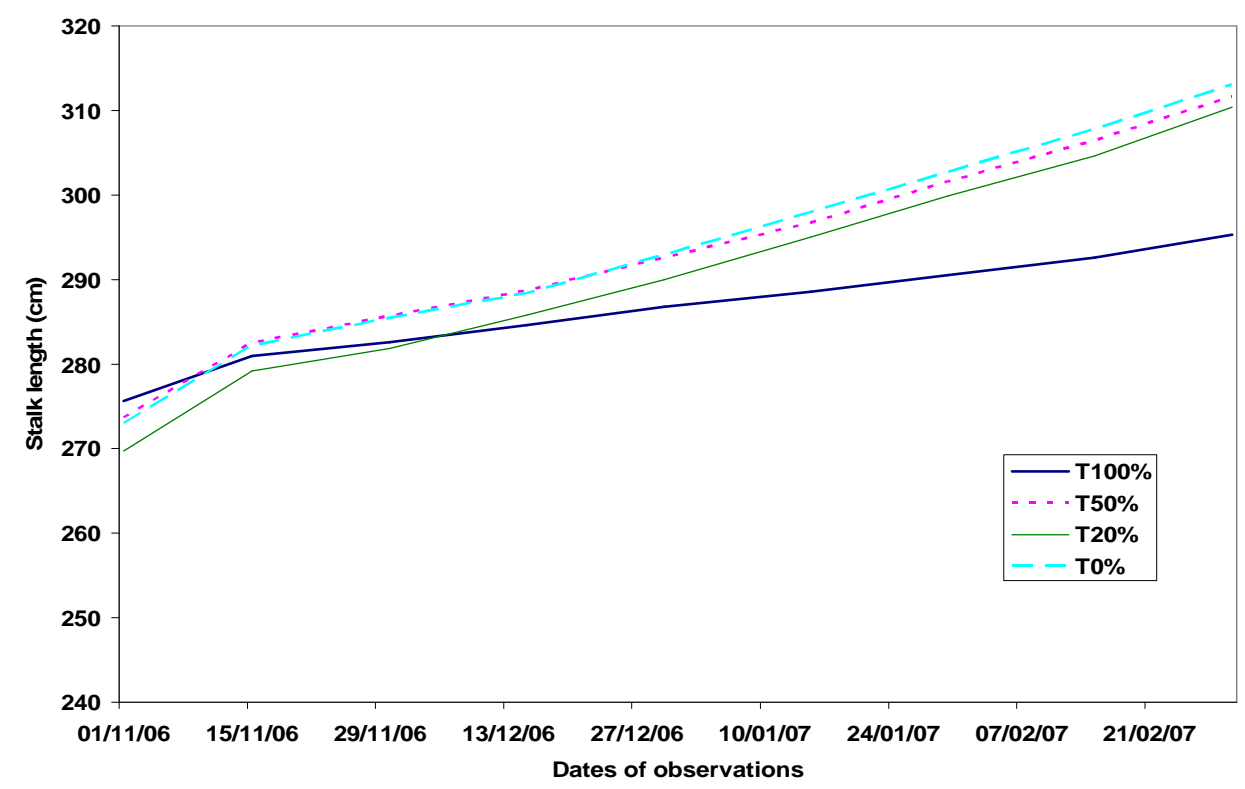

Figure 4: Cane growth response to soil water deficit imposed over the yield formation stage of a late season variety (Co 957) in Ferké 2 sugar mill (northern Ivory Coast). 


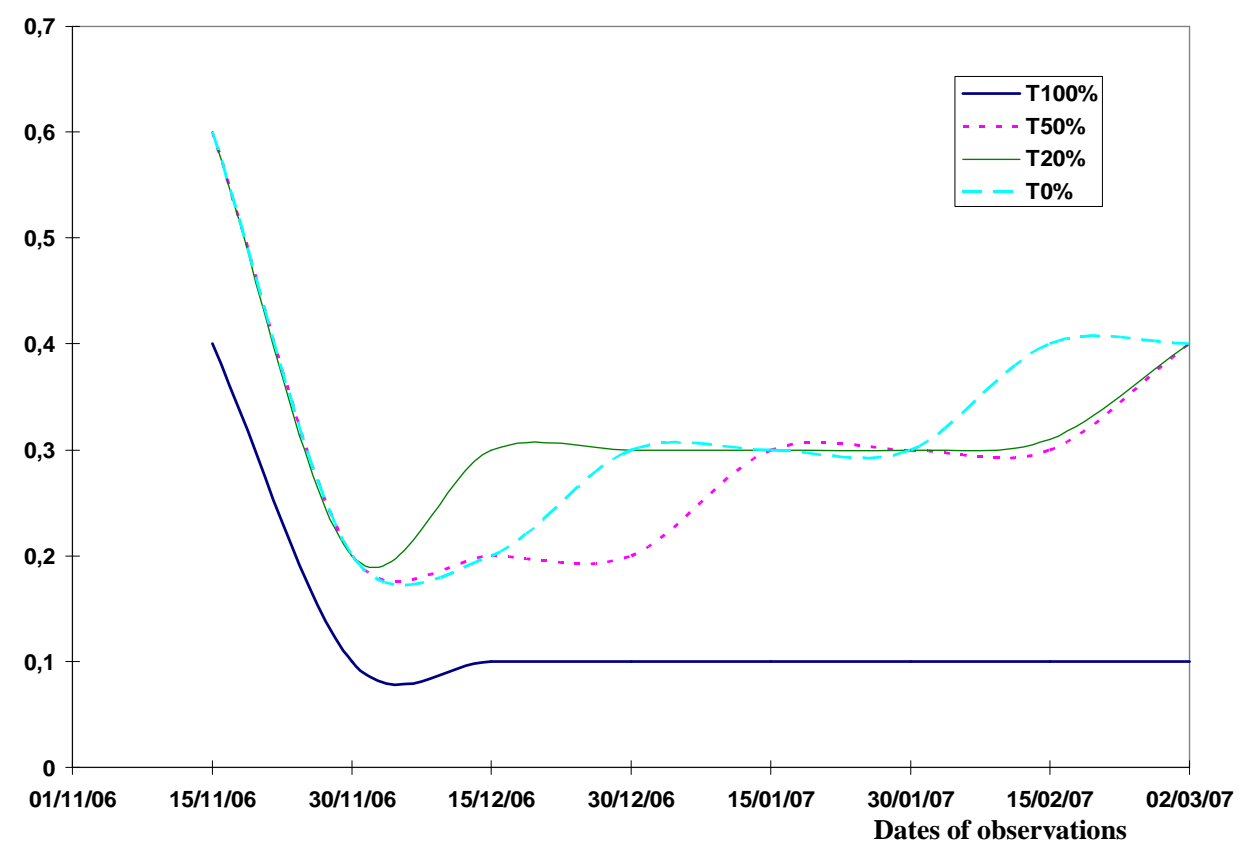

Figure 5: Cane stalk elongation rate over the yield formation stage of a late season variety (Co 957) in Ferké 2 sugar mill (northern Ivory Coast).

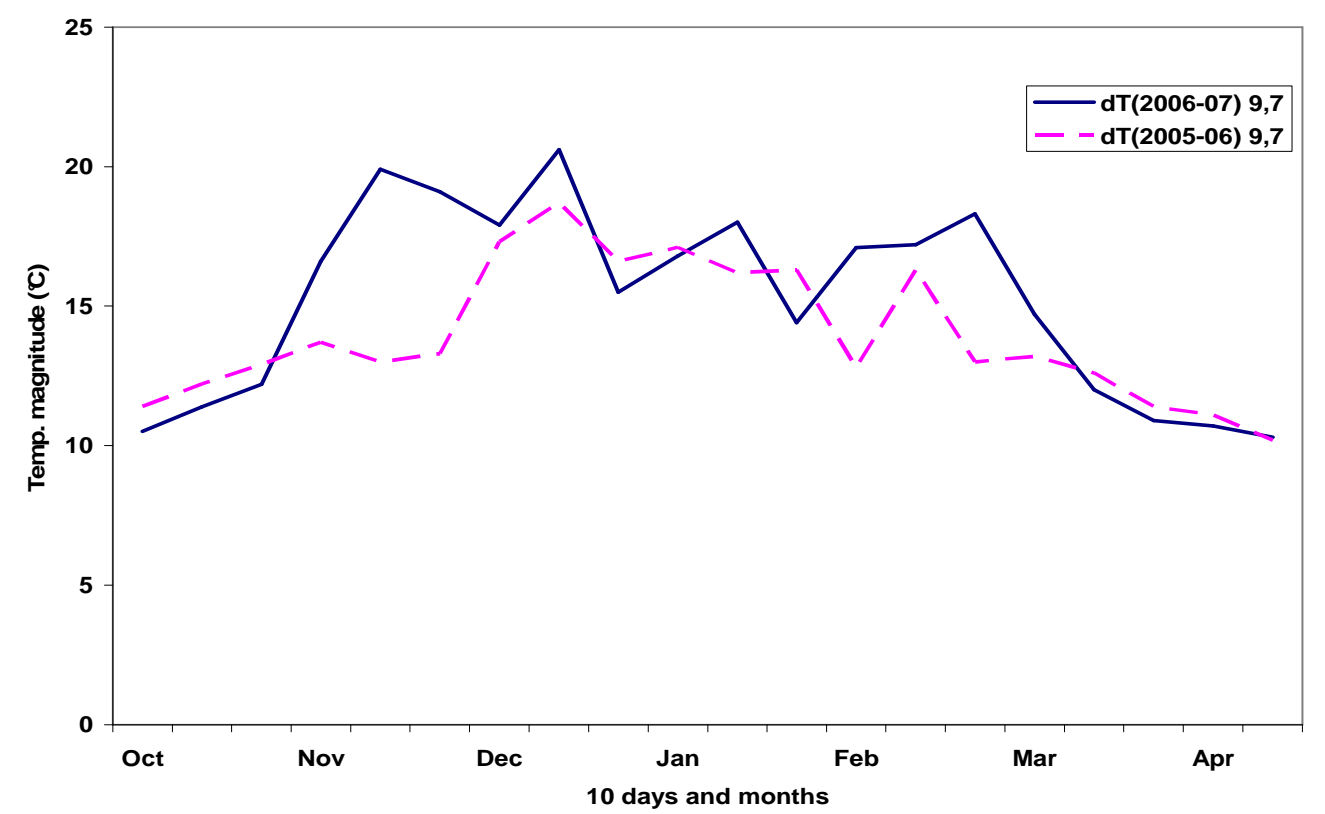

Figure 6a: Temperature magnitude variations over the yield formation stage of sugarcane [a late season variety (Co 957) in Ferké 2 sugar mill (northern Ivory Coast)]. 


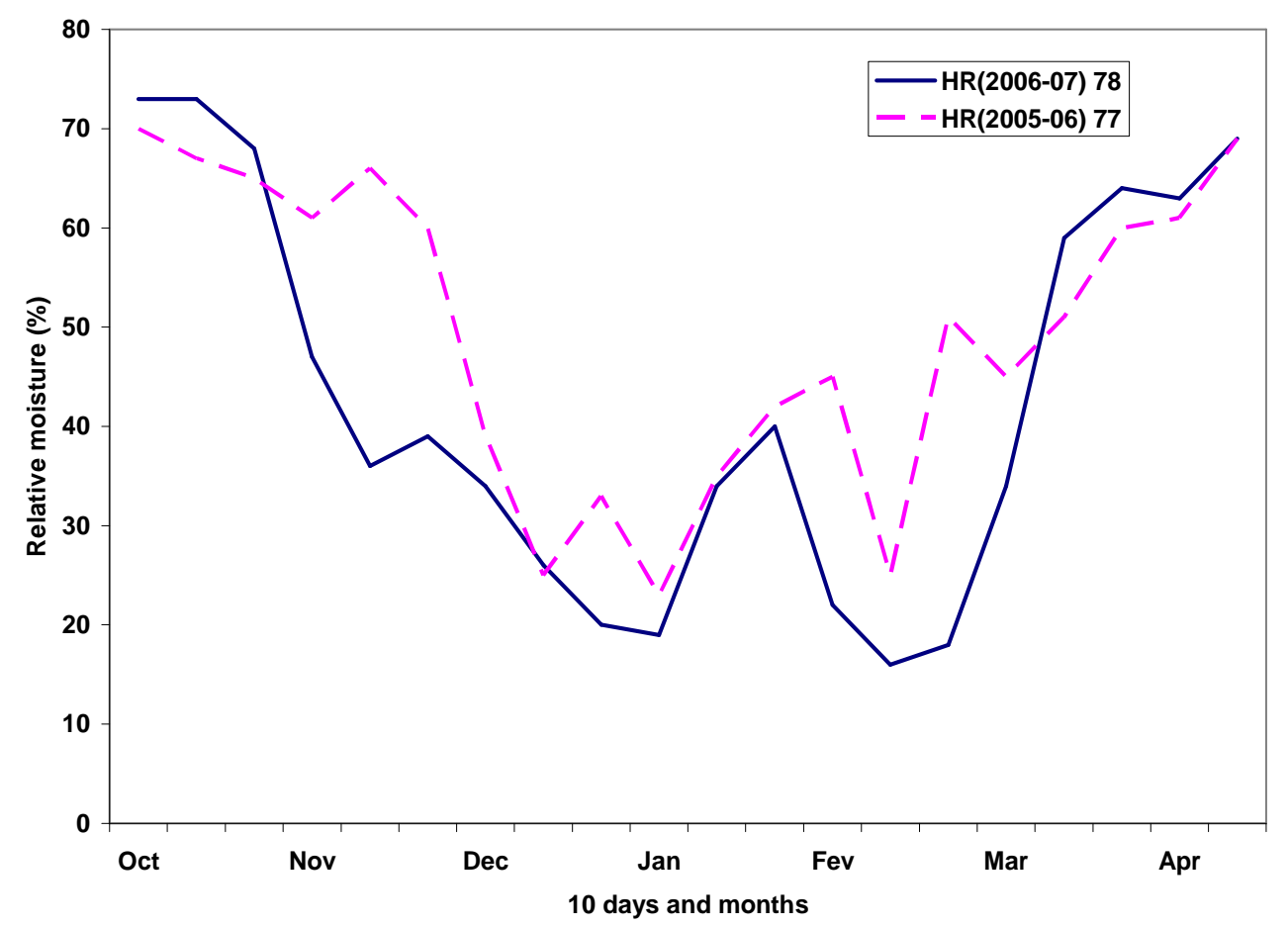

Figure 6b: Relative air moisture over the yield formation stage of sugarcane [a late season variety (Co 957) in Ferké 2 sugar mill (northern Ivory Coast)].

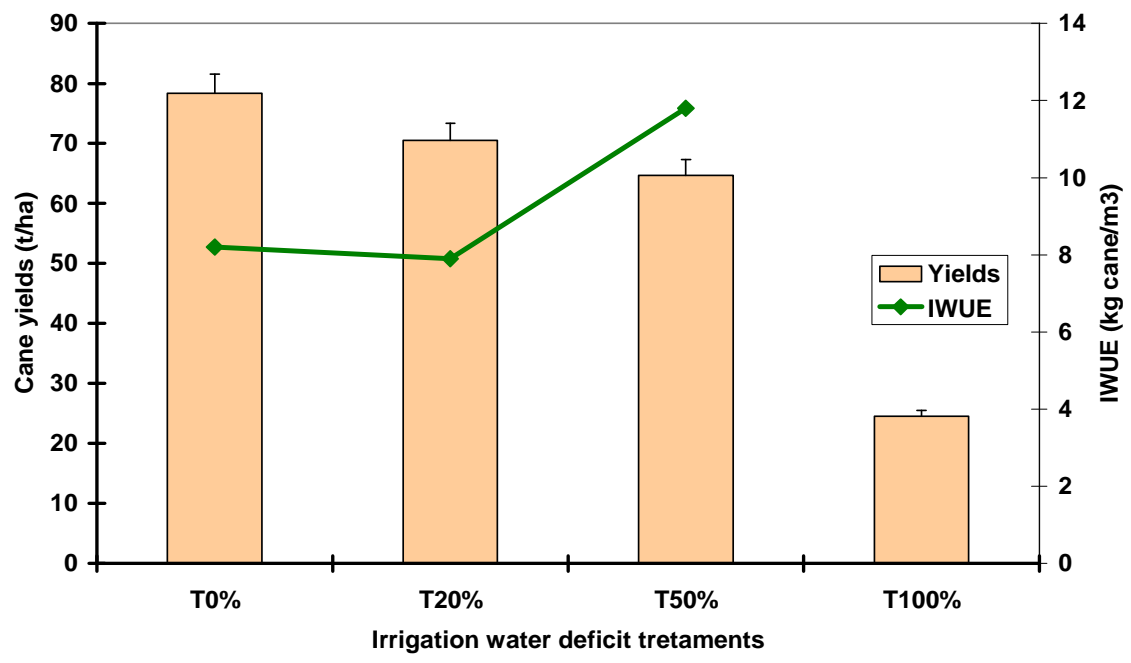

Figure 7: Cane yields and irrigation water use efficiency (IWUE) depending on water deficit treatments over the yield formation stage of a late season variety in Ferké 2 sugar mill (northern Ivory Coast). 
Table 1: Average data regarding irrigation depth, actual evapotranspiration, cane and sugar yields, juice quality.

\begin{tabular}{|c|c|c|c|c|c|c|c|c|}
\hline \multirow[t]{2}{*}{ Treatments } & \multirow{2}{*}{$\begin{array}{c}\text { Irrigatio } \\
\text { n (mm) }\end{array}$} & \multirow{2}{*}{$\begin{array}{c}\text { ETa } \\
(\mathrm{mm})\end{array}$} & \multicolumn{2}{|c|}{ Yields } & \multicolumn{4}{|c|}{ Juice quality } \\
\hline & & & $\begin{array}{l}\text { Cane } \\
\text { (t/ha) }\end{array}$ & $\begin{array}{c}\text { Sugar } \\
\text { (t/ha) }\end{array}$ & $\begin{array}{c}\text { Sucrose } \\
\text { (Pol\%) }\end{array}$ & $\begin{array}{l}\text { Purit } \\
\text { y }(\%)\end{array}$ & $\begin{array}{c}\text { Fiber } \\
(\%)\end{array}$ & $\begin{array}{l}\text { E.S. } \\
(\%)\end{array}$ \\
\hline T0\% & 777.5 & 1544.5 & $78.4 \mathrm{c}$ & $9.7 \mathrm{c}$ & 16.7 & 95.1 & 16.5 & 12.4 \\
\hline T20\% & 621.9 & 1464.1 & $70.5 \mathrm{bc}$ & $8.0 \mathrm{~b}$ & 16.2 & 92.2 & 16.0 & 12.4 \\
\hline Т50\% & 389.0 & 1224.8 & $64.5 \mathrm{~b}$ & $7.7 \mathrm{~b}$ & 16.1 & 90.6 & 15.6 & 12.0 \\
\hline T100\% & 0 & 885.5 & $24.5 \mathrm{a}$ & $3.0 \mathrm{a}$ & 15.7 & 87.9 & 15.1 & 11.3 \\
\hline Average & - & - & 59.5 & 7.1 & 16.2 & 91.5 & 15.8 & 12.0 \\
\hline Irrig effect & - & - & h.s. & h.s. & n.s. & n.s. & n.s. & n.s. \\
\hline CV $(\%)$ & - & - & 8.7 & 10.2 & 5.1 & 1.9 & 10.9 & 7.3 \\
\hline $\mathrm{SD}$ & - & - & 5.2 & 0.7 & 0.8 & 1.7 & 1.7 & 0.9 \\
\hline
\end{tabular}

Table 2: Soil physical and chemical properties in the experimental field at Ferké 2 sugar mill (northern Ivory Coast).

\begin{tabular}{lclc}
\hline Particle size distribution & \multicolumn{3}{c}{ Chemical properties } \\
\hline Sand $(\%)$ & 66 & $\mathrm{pH}$ & 6.5 \\
Clay $(\%)$ & 16 & Total nitrogen $(\%)$ & 0.04 \\
Silt $(\%)$ & 8 & Available phosphorous $(\mathrm{ppm})$ & 24 \\
Soil water holding capacity & & CEC (meq/100 g) & 5 \\
TAM (mm) & 70 & Sum of bases $(\mathrm{meq} / 100 \mathrm{~g})$ & 1.2 \\
RAM (mm) & 45 & Base saturation ratio $(\%)$ & 24 \\
& & Organic matter $(\%)$ & 1.3 \\
& & C/N & 15 \\
\hline
\end{tabular}

TAM: total available moisture over $60 \mathrm{~cm}$ depth RAM: readily available moisture

\section{Conclusion}

It came out that $20 \%$ water deficit was the optimum level which gave a field irrigation efficiency of $7.9 \mathrm{~kg}$ cane $/ \mathrm{m}^{3}$ of water, i.e., $0.98 \mathrm{~kg}$ sugar $/ \mathrm{m}^{3}$ of water. Also, lower cane stalk elongation rates $(0.2-0.4$ $\mathrm{cm} /$ day) as well as cane yields (24.5 - 78.4 t/ha) were obtained on a non-flowering late season variety like Co 957 as a result of an intensive and long lasting dry season observed over the yield formation stage. In line with that drought enhanced by the fresh and dry harmattan weather, a better cane juice quality was measured on Co 957 which used to be a moderately performing variety in Ferké 2 sugar mill. This finding is a sound contribution to a better water management strategy over the yield formation stage of late season cane varieties under cultivation in northern Ivory Coast.

\section{REFERENCES}

Garcia-Tejero I, Jiménez-Bocanegra JA, Duran-Zuazo VH, Romero-Vicente R. and Muriel-Fernandez JL. 2010. Positive impact of deficit irrigation on physiological response and fruit yield in citrus orchards: implications for 
sustainable water savings. J. Agricult. Sci. \& Technol., 4(3): 38-44.

Gaudin R, Brouwers M, Chopart JL. 1999. L'eau utile et les caractéristiques hydrodynamiques des sols sous culture de canne à sucre. Agricult. \& Dév., 24: 3038.

Kirda C. 2010. Deficit irrigation scheduling based on plant growth stages showing water stress tolerance. FAO Natural Resourc. \& Envir.

Kirda C, Topcu S, Kaman H, Yazici A and Derici MR. 2005. Grain yield response and $\mathrm{N}$-fertiliser recovery of maize under deficit irrigation. Field Crops Res., 93(23): 132-141.

Martiné JF. 1999. Croissance de la canne et stress hydrique: les apports d'un modèle plante. Agricult. \& Dév., 24: 21-28.

Ooerr SH, Cerda SH. 2005. Fire effects on soil system functioning: new insights and future challenges. Inter. J. Wildl. \& Fire, 14(4): 339-342.

Pankhurst CE, Magarey RC, Stirling GR, Blair BJ, Bell MJ, Garside AL. 2003. Management practices to improve soil health and reduce the effects of detrimental soil biota associated with yield decline of sugarcane in Queensland, Australia. Soil \& Til. Res., 72(2): 125137.

Péné CB. 1999. Diagnostic hydrique en culture cannière et gestion du risque climatique: cas de Ferké 2 et Zuénoula, en Côte d'Ivoire. Agricult. \& Dév., 24: 74-80.

Péné CB and Assa DA. 2005. Irrigation and fertiliser interactions under water deficit conditions in sugarcane, northern Côte d'Ivoire. Agron. Afr., 17(3): 189-200.
Péné CB and Edi GK. 1999. Sugarcane yield response to deficit irrigation at two growth stages. In Crop Yield Response to Deficit Irrigation: 136-147. Development in Plant and Soil Science (Vol. 84), Kirda C, Moutonnet P, Nielsen DR (eds). Kluwer Academic Publishers: Dordrecht, The Netherlands; 258.

Péné CB, Chopart JL, Assa DA. Gestion de l'irrigation à la parcelle en culture de canne à sucre (Saccharum officinarum L.) sous climat tropical humide: cas des régions nord et centre de la Côte d'Ivoire. Sécher., 8(2): 87-98.

Péné CB, Assa DA, Déa BG. 2001. Interactions eau d'irrigation-variétés de canne à sucre en conditions de rationnement hydrique. Cahiers Agricult., 10: 243-353.

Péné CB, Kéhé M. 2005. Performance de trois variétés de canne à sucre soumises au rationnement hydrique au Nord de la Côte d'Ivoire. Agron. Afr., 17(1): 7-18.

Péné CB, Koulibaly SG. 2011. Sugarcane yield variations in northern and central Ivory Coast as influenced by soil water balance over two growth stages. $J$. Agricult. Sci. \& Technol., 5(2): 220-225.

Robertson FA, Thorburn PJ. 2007a. Decomposition of sugarcane harvest residue in different climatic zones. Austral. J. Soil Res., 45(1): 1-11.

Robertson FA, Thorburn PJ. 2007b. Management of sugarcane harvest residues: Consequences for soil carbon and nitrogen. Austral. J. Soil Res., 45(1): 13-23. 